FOLIA POMERANAE UNIVERSITATIS TECHNOLOGIAE STETINENSIS

Folia Pomer. Univ. Technol. Stetin., Oeconomica 2017, 337(88)3, 13-22

\title{
SKŁONNOŚĆ POLAKÓW DO OSZCZĘDZANIA A ROZWÓJ DOBROWOLNYCH FORM GROMADZENIA OSZCZĘDNOŚCI EMERYTALNYCH
}

\author{
THE TENDENCY OF POLES TO SAVING AND THE DEVELOPMENT \\ OF VOLUNTARY FORMS OF PENSION SAVINGS
}

Katedra Analizy Systemowej i Finansów, Zachodniopomorski Uniwersytet Technologiczny w Szczecinie, ul. Klemensa Janickiego 31, 71-270 Szczecin, e-mail: elesna@zut.edu.pl

\begin{abstract}
Summary. The article analyzes the tendency of Poles to additional saving for retirement. The article presents the development of individual retirement accounts and individual retirement security accounts market in Poland between the years 2012 and 2016. Retirement coming only from the first and second pillar may be insufficient to ensure an appropriate level of retirement benefits. Therefore, individual retirement accounts and individual retirement security accounts, acting in the third pillar, should become an important component of future benefits. In recent years there has been little interest in the individual form of accumulation of retirement savings among citizens. There are some factors hindering the development of individual forms of saving, such as: low income, lack of habit of saving and lack of knowledge of individual retirement accounts and individual retirement security accounts functioning. Poles should have the necessary knowledge of fundraising to individual retirement accounts and individual retirement security accounts and the benefits of saving in their framework. The results of social research clearly point to the need for citizens' financial education and shaping their pension awareness.
\end{abstract}

Słowa kluczowe: skłonność do oszczędzania, dobrowolna forma oszczędzania, system emerytalny. Key words: the tendency to saving, voluntary form of saving, pension schemes.

\section{WSTĘP}

W ciągu ostatnich kilkunastu lat można zaobserwować w Polsce znaczące zmiany w strukturze wieku jej obywateli. Proces starzenia się społeczeństwa jest wynikiem wydłużania się przeciętnego trwania życia ludzkiego oraz spadku dzietności. Postęp w dziedzinie medycyny oraz równy dostęp wszystkich obywateli do kompleksowej, nowoczesnej opieki medycznej wpływają na poprawę stanu zdrowia Polaków i dłuższe życie.

W obliczu narastających problemów demograficznych niezwykle istotna jest skłonność Polaków do gromadzenia dodatkowych środków z przeznaczeniem na przyszłą emeryturę. Gromadzenie dodatkowych oszczędności może bowiem zapobiec znacznemu spadkowi dochodów po zakończeniu aktywności zawodowej. Tymczasem indywidualne konta emerytalne oraz indywidualne konta zabezpieczenia emerytalnego, które stanowią dobrowolne formy gromadzenia oszczędności emerytalnych w ramach III filara systemu emerytalnego, wciąż są 
mało popularne wśród obywateli ${ }^{1}$. Wiele osób nie posiada podstawowej wiedzy na temat funkcjonowania rynku finansowego lub ma jedynie podstawową wiedzę w tym zakresie. Osoby nieposiadające wiedzy ekonomiczno-finansowej często unikają podjęcia decyzji o oszczędzaniu i przekładają moment rozpoczęcia procesu gromadzenia oszczędności emerytalnych. Trzeci filar zabezpieczenia emerytalnego nie stanowi zatem istotnego uzupełnienia dwóch filarów obowiązkowych. Na koniec 2016 r. liczba uczestników IKE wyniosła 902,6 tys. osób (5,5\% pracujących), a wartość zgromadzonych aktywów na IKE - 6,7 mld zł. Na koniec 2016 r. liczba uczestników IKZE kształtowała się na poziomie 643,1 tys. osób (3,9\% pracujących), a wartość zgromadzonych aktywów osiągnęła 1,1 mld zł (UKNF 2017a). Dla porównania: w tym samym czasie liczba uczestników PPE wyniosła 396 tys., a wartość zgromadzonych aktywów - 11394 mln PLN (KNF 2017). Natomiast na koniec 2016 r. do OFE należało łącznie 16,4 mln członków, a wartość aktywów OFE wyniosła 153,4 mld PLN (UKNF 2017b).

Ze względu na niekorzystne tendencje demograficzne, społeczne i gospodarcze emerytura pochodząca tylko z I i II filara może okazać się niewystarczająca do zapewnienia odpowiedniego poziomu świadczeń emerytalnych. Dlatego niezwykle istotne jest upowszechnianie indywidualnego oszczędzania w ramach III filara systemu emerytalnego. W tym celu należy przede wszystkim przeprowadzić właściwe działania edukacyjno-informacyjne. Konieczna jest ogólnopolska kampania informacyjna, która uświadomi Polakom potrzebę gromadzenia dodatkowych środków emerytalnych.

Celem opracowania jest przedstawienie w sposób usystematyzowany problemu braku skłonności Polaków do oszczędzania na przyszłą emeryturę oraz charakterystyka dobrowolnych form gromadzenia oszczędności emerytalnych w Polsce.

\section{ŚWIADOMOŚĆ EMERYTALNA POLAKÓW}

W Polsce oszczędności gospodarstw domowych utrzymują się na bardzo niskim poziomie. Z badań wykonanych przez TNS Polska, na zlecenie Fundacji Kronenberga przy banku Citi Handlowy, wynika, że w 2013 r. ponad połowa Polaków (53\%) deklarowała, iż wszystkie swoje dochody przeznacza na bieżące potrzeby. Natomiast w tych samych badaniach na pytanie: Czy warto oszczędzać? prawie $24 \%$ respondentów oświadczyło, że oszczędzanie nie ma sensu, a $15 \%$ nie miało na ten temat zdania. Pozostała część ankietowanych $(61 \%)$ uznała, że warto oszczędzać z myślą o przyszłości. Relatywnie

\footnotetext{
${ }^{1}$ Od 1 stycznia 1999 r. istnieje w Polsce trzyfilarowy system emerytalny, przy czym pierwszy filar działa w oparciu o zasadę umowy międzypokoleniowej, a dwa pozostałe mają postać kapitałową. Pierwszy filar (ZUS) działa na podstawie zasady repartycji składek i świadczeń. Oznacza to, że wypłacane emerytury finansowane są ze składek osób aktualnie pracujących. W ramach drugiego filara funkcjonują otwarte fundusze emerytalne (OFE), których celem jest gromadzenie środków pieniężnych i ich lokowanie z przeznaczeniem na wypłatę członkom funduszu po osiągnięciu przez nich wieku emerytalnego (Ustawa $z$ dnia 28 sierpnia 1997 r., art. 2, ust. 1 i 2). Trzeci filar jest dobrowolnym elementem kapitałowo-ubezpieczeniowym w systemie emerytalnym. Od 1999 r. w zakresie tego filara występują pracownicze programy emerytalne (PPE), które są formą grupowego oszczędzania na emeryturę i które mogą być utworzone wyłącznie przez pracodawcę w celu gromadzenia oszczędności emerytalnych dla zatrudnionych przez niego pracowników. W połowie 2004 r. w ramach trzeciego filara stworzono możliwość gromadzenia środków na przyszłą emeryturę na indywidualnych kontach emerytalnych (IKE). Od 2012 r. możliwe jest również oszczędzanie na indywidualnych kontach zabezpieczenia emerytalnego (IKZE).
} 
częściej twierdziły tak osoby: z wykształceniem wyższym, o dochodach w gospodarstwie domowym powyżej 2500 PLN, z miast powyżej 200 tysięcy mieszkańców (TNS Polska dla Fundacji Kronenberga... 2013). Wynika z tego, iż skłonność do oszczędzania na przyszłą emeryturę ma związek z wykształceniem badanych - im jest ono wyższe, tym większy odsetek oszczędzających.

Z innych badań wykonanych przez Centrum Badania Opinii Społecznej (CBOS) wynika, iż $59 \%$ badanych nie odkłada dodatkowych pieniędzy na swoją emeryturę, ponieważ ich zarobki są niewystarczające. Natomiast $15 \%$ ankietowanych uważa, że ma jeszcze czas na rozpoczęcie oszczędzania. Wśród innych powodów braku oszczędzania na emeryturę wymieniano również brak wiedzy na temat skutecznych metod pomnażania oszczędności w dłuższym terminie (4\%). Natomiast $2 \%$ respondentów wierzy, że emerytury pochodzące ze składek na ZUS i OFE będą wystarczające do zapewnienia właściwych warunków życia na emeryturze - ryc. 1.

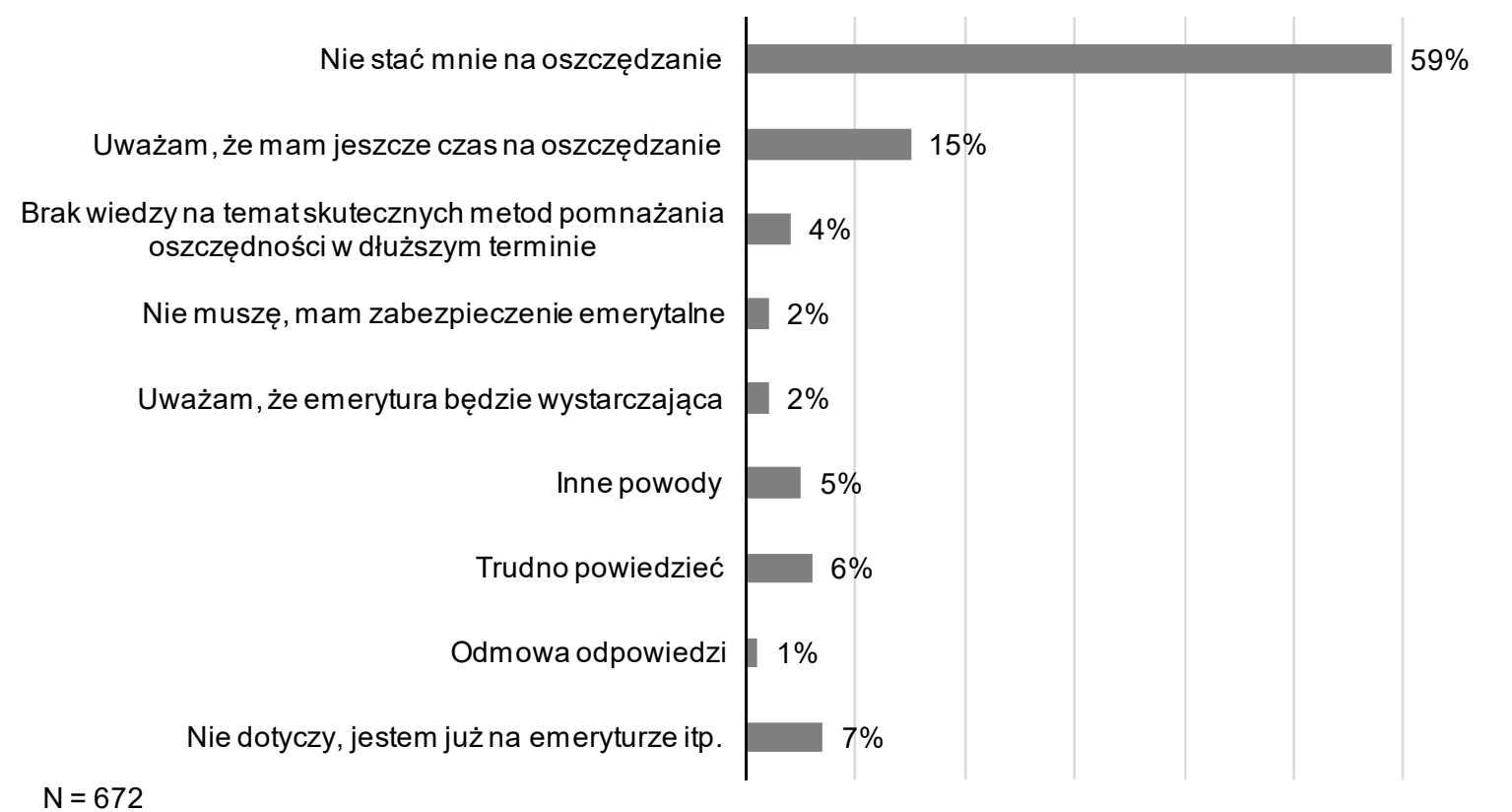

Ryc. 1. Dlaczego nie oszczędza Pan(-i) dodatkowo na emeryturę?

Źródło: opracowano na podstawie Centrum Badania Opinii Społecznej (2010).

Biorąc pod uwagę sposoby lokowania środków, 25\% oszczędzających deklaruje inwestowanie w ziemię czy nieruchomości. Wśród 22\% ankietowanych najpopularniejszą formą oszczędzania jest konto osobiste w banku. Nieco mniej popularne są konto oszczędnościowe w banku (21\% badanych) oraz polisa ubezpieczeniowa (18\%). Wśród osób oszczędzających dodatkowo na emeryturę jedynie $22 \%$ deklaruje posiadanie IKE (Indywidualnego Konta Emerytalnego). Znacznie mniejszym powodzeniem cieszy się oszczędzanie w ramach IKZE (Indywidualnego Konta Zabezpieczenia Emerytalnego). Z tej formy gromadzenia dodatkowych środków na emeryturę korzysta zaledwie $8 \%$ respondentów - ryc. 2. 


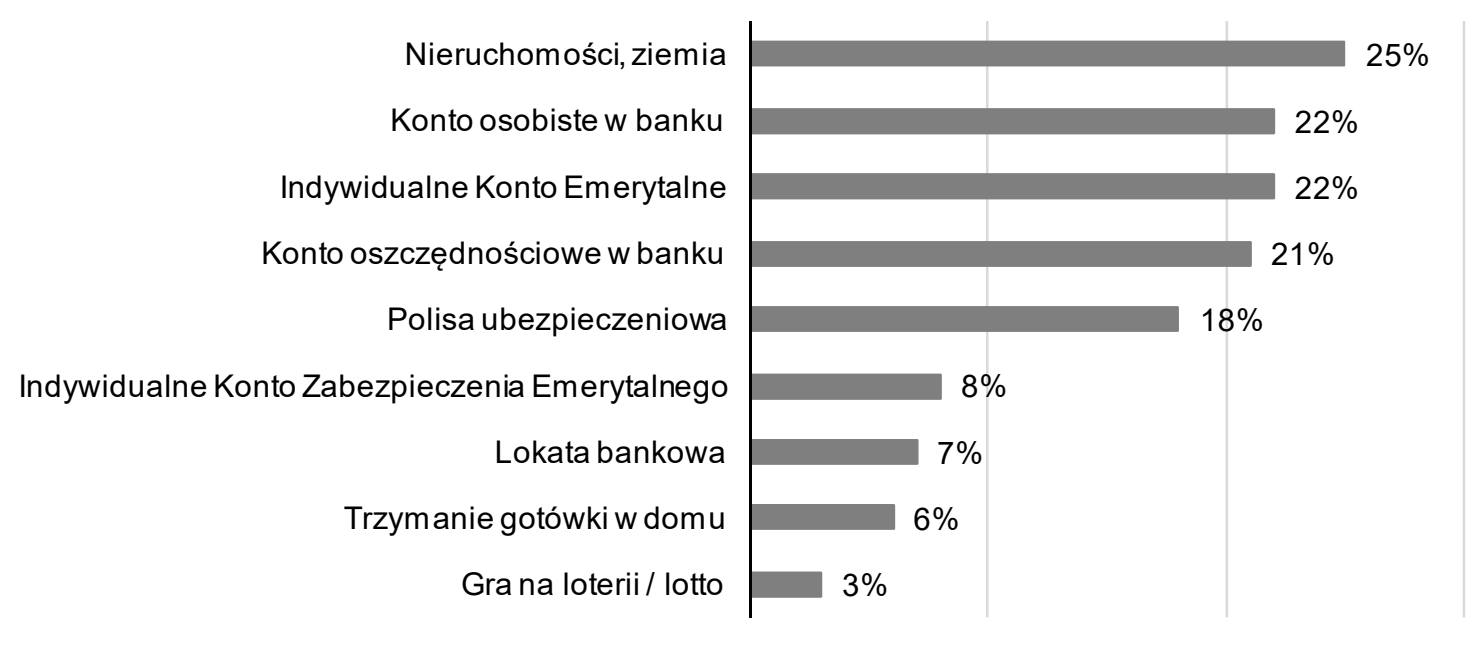

$\mathrm{N}=72$

Ryc. 2. Za pomocą jakich instrumentów finansowych oszczędza Pan(-i) dodatkowo na emeryturę? Źródło: opracowanie własne na podstawie TNS Polska dla Nationale-Nederlanden (2016).

Z badania pt. „Jak Polacy planują zabezpieczyć finansowo swoją przyszłość - czy zamierzają w tym celu korzystać z IKZE?", przeprowadzonego w kwietniu 2012 r. przez Centrum Badania Opinii Społecznej (CBOS), wynika, iż 86\% ankietowanych nie zna produktów oferowanych w ramach III filara - ryc. 3.

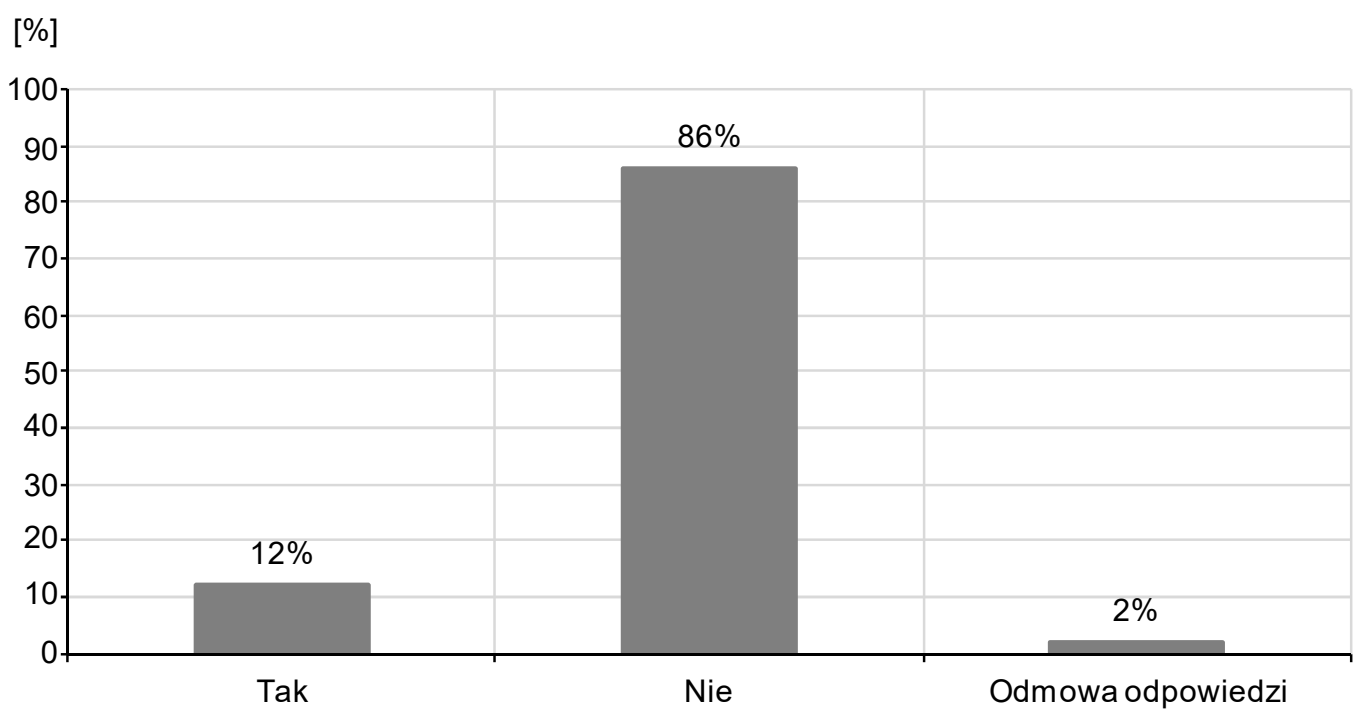

Ryc. 3. Czy zna Pan(-i) jakieś produkty finansowe, które umożliwiają oszczędzanie w III filarze? Źródło: opracowano na podstawie CBOS (2012).

\section{RYNEK IKE W POLSCE W LATACH 2012-2016}

Na koniec 2016 r. istniało w Polsce 902615 IKE, czyli o 47395 kont więcej niż na koniec roku 2015 (tab. 1). W 2016 r., podobnie jak w latach poprzednich, wśród oszczędzających na IKE najliczniejszą grupę stanowiły osoby w wieku 51-60 lat (249 349 IKE, 27,6\% kont). 
Najmniejszy odsetek kont (3,1\%) dotyczył osób najmłodszych oszczędzających na IKE (do 30 lat) w 2016 r. było to 27668 osób, czyli o 785 osób mniej niż w roku poprzednim. Spadek liczby funkcjonujących IKE w 2016 r., w porównaniu z rokiem poprzednim, odnotowano również w grupie wiekowej 31-40 lat (spadek o 5516 IKE). Zwiększenie liczby IKE w 2016 r., w porównaniu z rokiem 2015, dotyczyło natomiast osób w wieku 41-50 lat (wzrost o 11641 IKE), 51-60 lat (wzrost o 7816 IKE) oraz powyżej 60 lat (wzrost o 34239 IKE).

Tabela 1. Liczba IKE według wieku ich posiadaczy w latach 2012-2016

\begin{tabular}{|l|c|c|c|c|c|}
\hline \multirow{2}{*}{$\begin{array}{c}\text { Kategoria } \\
\text { wiekowa }\end{array}$} & \multicolumn{5}{|c|}{ Liczba IKE } \\
\cline { 2 - 6 } & 2012 & 2013 & 2014 & 2015 & 2016 \\
\hline Do 30 lat & 53010 & 41536 & 32477 & 28453 & 27668 \\
\hline 31-40 lat & 199945 & 193195 & 188220 & 180935 & 175419 \\
\hline $41-50$ lat & 197082 & 199948 & 205666 & 215485 & 227126 \\
\hline 51-60 lat & 238892 & 240283 & 238918 & 241533 & 249349 \\
\hline Powyżej 60 & 124363 & 142689 & 159204 & 188814 & 223053 \\
\hline Ogółem & 813292 & 817651 & 824485 & 855220 & 902615 \\
\hline
\end{tabular}

Źródło: opracowano na podstawie danych Urzędu Komisji Nadzoru Finansowego (2013-2017a).

Wzrost liczby IKE funkcjonujących w 2016 r., w porównaniu z rokiem poprzednim, zaobserwowano we wszystkich instytucjach finansowych prowadzących IKE, z wyjątkiem zakładów ubezpieczeń, w których liczba kont emerytalnych zmniejszyła się o 1981 (tab. 2). Największy przyrost liczby funkcjonujących IKE odnotowano w funduszach inwestycyjnych (34 289 IKE). Najwyższą dynamiką pod względem liczby prowadzonych IKE charakteryzowały się dobrowolne fundusze emerytalne, w przypadku których liczba prowadzonych kont emerytalnych zwiększyła się z 2548 na koniec 2015 r. do 3580 na koniec roku 2016.

Tabela 2. Liczba IKE prowadzonych przez poszczególne instytucje finansowe w latach 2012-2016

\begin{tabular}{|l|r|r|r|r|r|}
\hline \multicolumn{1}{|c|}{$\begin{array}{c}\text { Instytucje finansowe } \\
\text { prowadzące IKE }\end{array}$} & 2012 & 2013 & 2014 & 2015 & 2016 \\
\cline { 2 - 6 } & 557595 & 562289 & 573515 & 573092 & 571111 \\
\hline Zakłady ubezpieczeń & 188102 & 182807 & 174515 & 201989 & 236278 \\
\hline Fundusze inwestycyjne & 20079 & 21712 & 22884 & 25220 & 27615 \\
\hline $\begin{array}{l}\text { Podmioty prowadzące } \\
\text { działalność maklerską }\end{array}$ & 47037 & 49370 & 51625 & 52371 & 64031 \\
\hline Banki & 479 & 1473 & 1946 & 2548 & 3580 \\
\hline $\begin{array}{l}\text { Dobrowolne fundusze } \\
\text { emerytalne }\end{array}$ & 813292 & 817651 & 824485 & 855220 & 902615 \\
\hline Ogółem & &
\end{tabular}

Źródło: opracowano na podstawie danych Urzędu Komisji Nadzoru Finansowego (2013-2017a).

Wzrost wartości aktywów IKE można zaobserwować w całym analizowanym okresie (tab. 3). Wartość aktywów zgromadzonych na IKE na koniec 2016 r. wyniosła 6655497 tys. PLN i wzrosła o 1010515 tys. PLN (tj. o 17,9\%) w stosunku do wartości aktywów na koniec roku 2015. W roku 2016 powiększenie wartości aktywów, w porównaniu z 2015 r., dotyczyło wszystkich instytucji finansowych:

- w zakładach ubezpieczeń - wzrost o 222702 tys. PLN,

- w funduszach inwestycyjnych - wzrost o 299330 tys. PLN,

- w podmiotach prowadzących działalność maklerską - wzrost o 172654 tys. PLN,

- w bankach - wzrost o 305659 tys. PLN,

- w dobrowolnych funduszach emerytalnych - wzrost o 10170 tys. PLN. 
Tabela 3. Aktywa IKE w latach 2012-2016

\begin{tabular}{|l|r|r|r|r|r|}
\hline \multirow{2}{*}{$\begin{array}{l}\text { Instytucje finansowe } \\
\text { prowadzące IKE }\end{array}$} & \multicolumn{5}{|c|}{ Aktywa IKE [tys. PLN] } \\
\cline { 2 - 6 } & 2012 & 2013 & 2014 & 2015 & 2016 \\
\hline Zakłady ubezpieczeń & 1397176 & 1618173 & 1903628 & 2060309 & 2283011 \\
\hline Fundusze inwestycyjne & 1128873 & 1337534 & 1513289 & 1695828 & 1995158 \\
\hline $\begin{array}{l}\text { Podmioty prowadzące } \\
\text { działalność maklerską }\end{array}$ & 524254 & 676461 & 790231 & 902974 & 1075628 \\
\hline Banki & 477896 & 627587 & 804440 & 960453 & 1266112 \\
\hline $\begin{array}{l}\text { Dobrowolne fundusze } \\
\text { emerytalne }\end{array}$ & 2114 & 11395 & 18949 & 25418 & 35588 \\
\hline Ogółem & 3530313 & 4271150 & 5030537 & 5644982 & 6655497 \\
\hline
\end{tabular}

Źródło: opracowano na podstawie danych Urzędu Komisji Nadzoru Finansowego (2013-2017a).

\section{RYNEK IKZE W POLSCE W LATACH 2012-2016}

Od 1 stycznia 2012 r., oprócz IKE, dodatkową możliwość indywidualnego oszczędzania w ramach trzeciego filara stanowią indywidualne konta zabezpieczenia emerytalnego. $\mathrm{Na}$ koniec 2016 r. istniało w Polsce 643112 IKZE, czyli o 45853 kont więcej niż na koniec roku 2015 (tab. 4). W roku 2016, podobnie jak w latach poprzednich, największy udział w liczbie funkcjonujących IKZE miały osoby z przedziałów wiekowych: od 31 do 40 lat, od 41 do 50 lat oraz od 51 do 60 lat. Udział osób ze wskazanych grup wiekowych rozkładał się równomiernie w granicach $25-28 \%$. Znacznie mniejszy udział miały osoby w wieku do 30 lat posiadające IKZE (tj. 9,3\% kont). W 2016 r. było to 59940 osób, czyli o 8788 osób mniej niż w roku poprzednim. Najmniej kont $(10,5 \%)$ posiadały osoby w wieku powyżej 60 lat.

Tabela 4. Liczba IKZE według wieku ich posiadaczy w latach 2012-2016

\begin{tabular}{|l|r|r|r|r|r|}
\hline \multirow{2}{*}{ Kategoria wiekowa } & \multicolumn{5}{|c|}{ Liczba IKZE } \\
\cline { 2 - 6 } & 2012 & 2013 & 2014 & 2015 & 2016 \\
\hline Do 30 lat & 98984 & 82354 & 72575 & 68728 & 59940 \\
\hline 31-40 lat & 135181 & 137713 & 144097 & 156963 & 161494 \\
\hline 41-50 lat & 134489 & 133315 & 144169 & 161555 & 173517 \\
\hline 51-60 lat & 121920 & 131715 & 144951 & 165998 & 180587 \\
\hline 61-65 lat & 5394 & 10420 & 19808 & 35080 & 53769 \\
\hline Powyżej 65 lat & 853 & 919 & 2542 & 8935 & 13805 \\
\hline Ogółem & 496821 & 496436 & 528142 & 597259 & 643112 \\
\hline
\end{tabular}

Źródło: opracowano na podstawie danych Urzędu Komisji Nadzoru Finansowego (2013-2017a).

$\mathrm{Na}$ koniec 2016 r. instytucje finansowe uprawnione do prowadzenia IKZE obsługiwały łącznie 643112 kont, przy czym dominującą pozycję wśród prowadzących IKZE w całym analizowanym okresie miały zakłady ubezpieczeń (69,4\% udziału w rynku) - tab. 5. Od początku funkcjonowania IKZE, czyli od 2012 r., umowy o prowadzenie konta oszczędzający zawierali głównie z zakładami ubezpieczeń, a w dalszej kolejności z dobrowolnymi funduszami emerytalnymi. Jednocześnie to właśnie $w$ tych instytucjach zanotowano najniższą dynamikę wzrostu liczby IKZE: w zakładach ubezpieczeń - 0,7\%, a dobrowolnych funduszach emerytalnych - 6,6\%. W 2016 r. na popularności zyskało oszczędzanie w funduszach inwestycyjnych - w tym przypadku liczba IKZE wzrosła aż o 61,5\%. Na koniec 2016 r. w podmiotach prowadzących działalność maklerską i w bankach znalazło się jedynie 2,4\% wszystkich IKZE. 
Tabela 5. Liczba IKZE prowadzonych przez poszczególne instytucje finansowe w latach 2012-2016

\begin{tabular}{|l|r|r|r|r|r|}
\hline \multirow{2}{*}{ Instytucje finansowe prowadzące IKZE } & \multicolumn{5}{|c|}{ Liczba IKZE } \\
\cline { 2 - 6 } & \multicolumn{1}{|c|}{2012} & 2013 & \multicolumn{1}{c|}{2014} & \multicolumn{1}{c|}{2015} & \multicolumn{1}{c|}{2016} \\
\hline Zakłady ubezpieczeń & 363399 & 388699 & 418935 & 442735 & 446054 \\
\hline Fundusze inwestycyjne & 5202 & 9565 & 17510 & 54170 & 87510 \\
\hline $\begin{array}{l}\text { Podmioty prowadzące } \\
\text { działalność maklerską }\end{array}$ & 559 & 1012 & 2797 & 4325 & 6201 \\
\hline Banki & 19 & 33 & 8105 & 13735 & 15585 \\
\hline Dobrowolne fundusze emerytalne & 127642 & 97127 & 80795 & 82294 & 87762 \\
\hline Ogółem & 496821 & 496436 & 528142 & 597259 & 643112 \\
\hline
\end{tabular}

Źródło: opracowano na podstawie danych Urzędu Komisji Nadzoru Finansowego (2013-2017a).

Wzrost wartości aktywów IKZE można zaobserwować w całym analizowanym okresie oraz we wszystkich rodzajach instytucji finansowych prowadzących IKZE (tab. 6). W roku 2016 wartość aktywów zgormadzonych na IKZE wyniosła 1078090 tys. PLN i wzrosła o 458498 tys. PLN (tj. o 74\%) w stosunku do wartości aktywów na koniec roku 2015. Z uwagi na najmniejszy wzrost aktywów IKZE w zakładach ubezpieczeń zmniejszył się również ich udział w aktywach ogółem, głównie na rzecz funduszy inwestycyjnych, które na koniec 2016 roku miały największy udział w aktywach IKZE (37,8\%). Podtrzymana została tym samym obserwowana we wcześniejszych latach tendencja utraty pozycji przez zakłady ubezpieczeń na rzecz funduszy inwestycyjnych.

Tabela 6. Aktywa IKZE w latach 2012-2016

\begin{tabular}{|l|r|r|r|r|r|}
\hline \multirow{2}{*}{ Instytucje finansowe prowadzące IKZE } & \multicolumn{5}{|c|}{ Aktywa IKZE [tys. PLN] } \\
\cline { 2 - 6 } & 2012 & 2013 & 2014 & \multicolumn{1}{c|}{2015} & 2016 \\
\hline Zakłady ubezpieczeń & 36393 & 75117 & 167737 & 281946 & 398589 \\
\hline Fundusze inwestycyjne & 7973 & 23371 & 63559 & 193099 & 407884 \\
\hline $\begin{array}{l}\text { Podmioty prowadzące } \\
\text { działalność maklerską }\end{array}$ & 1673 & 4815 & 14638 & 30268 & 57045 \\
\hline Banki & & & & & \\
\hline Dobrowolne fundusze emerytalne & 6803 & 15805 & 37792 & 79198 & 147972 \\
\hline Ogółem & 52882 & 119206 & 295350 & 619592 & 1078090 \\
\hline
\end{tabular}

Źródło: opracowano na podstawie danych Urzędu Komisji Nadzoru Finansowego (2013-2017a).

\section{PODSUMOWANIE}

Ze względu na zmiany demograficzne emerytura pochodząca tylko z I i II filara może okazać się niewystarczająca do zapewnienia odpowiedniego poziomu świadczeń emerytalnych. Dlatego istotnym elementem przyszłego świadczenia powinny stać się indywidualne konta emerytalne oraz indywidualne konta zabezpieczenia emerytalnego funkcjonujące w ramach III filara.

W ostatnich latach można zaobserwować niewielkie zainteresowanie indywidualną formą gromadzenia oszczędności emerytalnych wśród obywateli. Przyczyn takiego stanu rzeczy należy szukać przede wszystkim w: zbyt niskich dochodach, braku nawyku oszczędzania oraz niedostatecznej wiedzy z zakresu funkcjonowania IKE i IKZE.

$\mathrm{Na}$ koniec 2016 r. IKE posiadało 902615 osób, które zgromadziły na kontach aktywa o wartości 6655497 tys. PLN, natomiast 643112 oszczędzających na IKZE posiadało 1078090 tys. zł aktywów. Analiza struktury wieku posiadaczy IKE i IKZE pokazuje związek pomiędzy wiekiem osoby posiadającej konto emerytalne a rodzajem wybieranego konta. Im 
młodsza osoba oszczędzająca na przyszłe świadczenia emerytalne, tym chętniej dokonywała wyboru IKZE, zaś starsza - IKE. W 2016 r. osoby w wieku do 30 lat posiadały 59940 IKZE oraz 27668 IKE. Także osoby w wieku od 31 do 50 lat przy podejmowaniu decyzji o utworzeniu konta emerytalnego w jednej ze wskazanych form częściej wybierały IKZE, kierując się korzyścią wynikającą z możliwości dokonania odliczenia $w$ rocznym rozliczeniu podatku od dochodów osobistych. Natomiast osoby oszczędzające na cele emerytalne w wieku powyżej 60 lat posiadały 223053 IKE oraz 67574 IKZE.

W celu upowszechnienia indywidualnego oszczędzania należy przede wszystkim przeprowadzić właściwe działania edukacyjno-informacyjne. Należy organizować debaty społeczne z udziałem ekspertów oraz utrzymywać zainteresowanie mediów kwestiami emerytur. Uczestnicy systemu emerytalnego powinni posiadać niezbędną wiedzę o gromadzeniu środków na indywidualnych kontach emerytalnych i indywidualnych kontach zabezpieczenia emerytalnego oraz o korzyściach wynikających z oszczędzania w ich ramach.

\section{PIŚMIENNICTWO}

Centrum Badania Opinii Społecznej. 2010. Polacy o dodatkowym oszczędzaniu na emeryturę, http://www.cbos.pl/SPISKOM.POL/2010/K_077_10.PDF, dostęp: 17.05.2017.

Centrum Badania Opinii Społecznej. 2012. Jak Polacy planują zabezpieczyć finansowo swoją przyszłość - czy zamierzają w tym celu korzystać z IKZE? http://docplayer.pl/5901671-Jak-polacyplanuja-zabezpieczyc-finansowo-swoja-przyszlosc, dostęp: 20.05.2017.

Komisja Nadzoru Finansowego. 2017. Sprawozdanie z działalności Komisji Nadzoru Finansowego w 2016 roku, https://www.knf.gov.pl/Images/Sprawozdanie_KNF_2016_tcm75-49950.pdf, dostęp: 15.05.2017.

TNS Polska dla Fundacji Kronenberga przy banku Citi Handlowy. 2013. Postawy Polaków wobec oszczędzania, http://www.citibank.pl/poland//kronenberg/polish/files/fk_oszcz_2013.pdf, dostęp: 15.05.2017.

TNS Polska dla Nationale-Nederlanden. 2016. Skłonność Polaków do dodatkowego oszczędzania na emeryturę - mit czy rzeczywistość? http://www.tnsglobal.pl/coslychac/files/2016/03/Sklonnoscdo-oszczedzania-na-emeryture, dostęp: 20.05.2017.

Urząd Komisji Nadzoru Finansowego. 2013. Indywidualne konta emerytalne oraz indywidualne konta zabezpieczenia emerytalnego w 2012 roku. Warszawa, KNF, 8-10.

Urząd Komisji Nadzoru Finansowego. 2014. Indywidualne konta emerytalne oraz indywidualne konta zabezpieczenia emerytalnego w 2013 roku. Warszawa, KNF, 8-10.

Urząd Komisji Nadzoru Finansowego. 2015. Indywidualne konta emerytalne oraz indywidualne konta zabezpieczenia emerytalnego w 2014 roku. Warszawa, KNF, 8-10.

Urząd Komisji Nadzoru Finansowego. 2016. Indywidualne konta emerytalne oraz indywidualne konta zabezpieczenia emerytalnego w 2015 roku. Warszawa, KNF, 8-10.

Urząd Komisji Nadzoru Finansowego. 2017a. Indywidualne konta emerytalne oraz indywidualne konta zabezpieczenia emerytalnego w 2016 roku. Warszawa, KNF, 8-10.

Urząd Komisji Nadzoru Finansowego. 2017b. Rynek otwartych funduszy emerytalnych w IV kwartale 2016 roku. Warszawa, KNF, 6, 12.

Ustawa $z$ dnia 28 sierpnia 1997 roku o organizacji i funkcjonowaniu funduszy emerytalnych. DzU z 1997 r., nr 139, poz. 934.

Streszczenie. W artykule przeanalizowano skłonność Polaków do dodatkowego oszczędzania na emeryturę, a ponadto scharakteryzowano rynek IKE i IKZE w Polsce w latach 2012-2016. Emerytura pochodząca tylko z I i II filara może okazać się niewystarczająca do zapewnienia odpowiedniego poziomu świadczeń emerytalnych. Dlatego ważnym elementem przyszłego świadczenia powinny stać się indywidualne konta emerytalne oraz indywidulane konta 
zabezpieczenia emerytalnego funkcjonujące w ramach III filara. W ostatnich latach można zaobserwować niewielkie zainteresowanie indywidualną formą gromadzenia oszczędności emerytalnych wśród obywateli. Do barier rozwoju indywidualnych form oszczędzania należy zaliczyć: niskie dochody, brak nawyku oszczędzania oraz brak wiedzy z zakresu funkcjonowania IKE i IKZE. Polacy powinni posiadać niezbędną wiedzę o gromadzeniu środków na indywidualnych kontach emerytalnych i indywidualnych kontach zabezpieczenia emerytalnego oraz korzyściach wynikających z oszczędzania w ich ramach. Wyniki badań społecznych wyraźnie wskazują na potrzebę edukacji finansowej obywateli i kształtowania ich świadomości emerytalnej. 
